University of Thi-Qar Joumal Of Science (UTsci)
Website: http://jsci.utq.edu.iq

Volume 6, Number 1, December 2016

\title{
Isolation, Purification and Identification of Active Chemical Compound Lup-20(29)-ene- 3, 28-diol (Betulin) from Tetradium daniellii Leaves and Study the hypoglycemic Effect on Rabbits
}

\author{
Jamal Harbi Hussien Alsaadi \\ Department of Chemistry - College of Science - University of Thi-Qar - Thi-Qar - Iraq
}

E-mail: noorjamal713@yahoo.com

Mobile: 07801305318

\begin{abstract}
$\underline{\text { Abstract }}$
Diabetes mellitus is a syndrome and serious complex chronic condition leading to higher blood glucose levels that is a major source of health disorder worldwide, about 171 million or more diabetes mellitus cases worldwide in patients ages 20 years or more. The active chemicals compounds that isolated from medicinal plants were used succifully to treat this disease .the current study was extracted and isolated the bioactive compound (Lup-20(29)-ene-3, 28- diol ) from (Tetradium daniellii ) leaves. Were isolated, separated, purified and identified by thin layer chromatography, column chromatography, gas chromatography, IR-spectroscopy, ${ }^{1} \mathrm{H}-\mathrm{NMR}, \mathrm{C}^{13}$-NMR,dept-NMR, Gas chromatography - mass spectroscopy. Also study of hypoglycemic action in blood glucose levels in normalglycemic and alloxan induced diabetic rabbits of Lup-20(29)-ene-3, 28-diol compound, a significant decreasing $(\mathrm{P}<0.01)$ at fourth and sixth hrs , and high significant decreasing $(\mathrm{P}<0.001)$ at twenty forth hrs. in hyperglycemic rabbits, while in no rmalglycaemic rabbits, a significant decline $(\mathrm{P}<0.05)$ was at sixth, and a high significant decreasing $(\mathrm{P}<0.01)$ was recorded at twenty forth hrs.
\end{abstract}

Key world: Tetradium daniellii, Betulin, hyperglycemia.

عزل , تنقية وتثخيص المركب الكيميائي الفعال Lup-20(29)-ene-3, 28-diol من أولق نبات Tetradium daniellii

$$
\begin{aligned}
& \text { جمال حربي حسين السعدي } \\
& \text { قسم الكيمياء - كلية العلوم - جامعة ذي قار - العراق }
\end{aligned}
$$

الخلاصة

داء السكر هو أضطرب في عملية أيض سكر الكلوكوز في الجسم يؤدي إلى ارتفاع مستوبات هذا السكر في الدم بصورة غير طبيعية لأسباب مختلفة

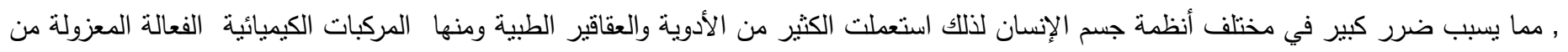

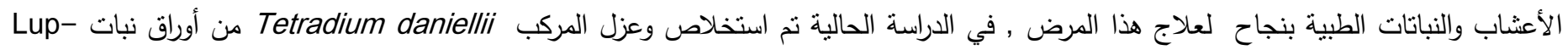

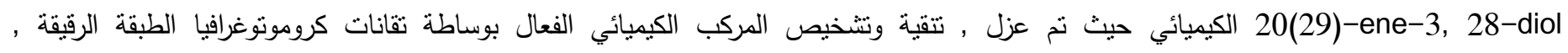

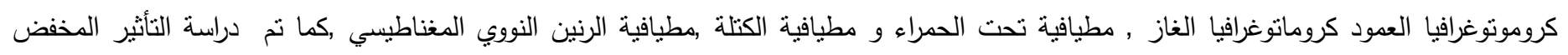




\section{University of Thi-Qar Joumal Of Science (UTsci)}

Website: http://jsci.utq.edu.iq

Volume 6, Number 1, December 2016

$$
\begin{aligned}
& \text { لسكر الكلكوز في الأرانب المختبرية للمركب الكيميائي المعزول Lup-20(29)-ene-3, 28-diol لوحظ فعالية قوية في تخفيض مسنويات كلكوز الدم , }
\end{aligned}
$$

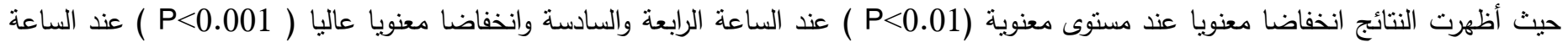

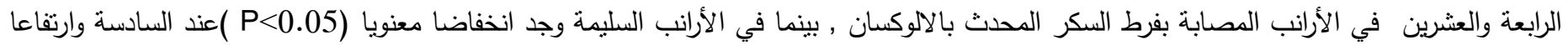

$$
\begin{aligned}
& \text { معنويا عاليا (P>0.01 ) عند الساعة الرابعة والعشرين . }
\end{aligned}
$$

\section{Introduction :}

The term diabetes mellitus describes a metabolic disorder of multiple aetiology characterized by chronic hyperglycemia with disturbances of carbohydrate, fat and protein metabolism resulting from defects in insulin secretion, insulin action, or both (Moore et al.,2009). The effects of diabetes mellitus include long- term damage, dysfunction and failure of various organs. Diabetes mellitus may present with characteristic symptoms such as thirst, polyuria, blurring of vision, and weight loss. In its most severe forms, ketoacidosis or a non-ketotic hyperosmolar state may develop and lead to stupor, coma and, in absence of effective treatment, death. Often symptoms are not severe, or may be absent, and consequently hyperglycaemia sufficient to cause pathological and functional changes may be present for a long time before the diagnosis is made(WHO,2006; ADA ,2012) .Diabetes federaion (2011),reported that 366 million people have diabetes in 2011 and by 2030 million would have risen to 552 million .It was also estimated that diabetes causes 4.6 million deaths (International Diabetes Federation ,2014) . Currently available treatment options in modern medicine have several adverse effects. Therefore there is a need to develop safe and effective treatment modalities for diabetes. Medical plants play an important role in the management of DM especially in developing countries. More than 400 plants have been incorporated in approximately 700 recipes which are used to treat (Chauhan et al.,2010 ; Das Gupta and De,2012). a plant commonly used in the Mediterranean traditional medicine for its antidiabetic properties, sedative, analgesic, anti-inflammatory and hypoglycemic activities (Yessoufou et al.,2013). There have been many studies on hypoglycaemic plants and a great variety of compounds have been isolated (alkaloids glycosides, terpenes ,phenols and flavonoids( Andrade-Cetto, and Heinrich,2005; ElHouri et al., 2014 ).Tetradium daniellii (Benn.) commonly known as (Korean evodia, Rutaceae) belongs to family Rutaceae, the table ( 1) showing scientific classification, occurring in temperate to tropical east Asia is native to Tibet and the Yunnan Province, China, northeast through China to North and South Korea and some parts of Europe (Hartley 1981)

Table (1) scientific classification of Tetradium daniellii ( Vincent,2004).

\begin{tabular}{|cc|}
\hline \hline Kingdom: & Plantae \\
\hline \hline (unranked): & Angiosperms \\
\hline \hline (unranked): & Eudicots \\
\hline \hline (unranked): & Rosids \\
\hline \hline Order: & Sapindales \\
\hline \hline Family: & Rutaceae \\
\hline Genus: & $\begin{array}{c}\text { Tetradium } \\
\text { daniellii }\end{array}$ \\
\hline \hline
\end{tabular}

A moderate-sized tree or large shrub, reaching 812(-20) $\mathrm{m}$ tall, with a similar spread of the crown. Its bark is smooth and gray to black. The young branches are pubescent becoming glabrous as the growing season progresses; winter buds are naked Leaves are 22-40 cm long(Anonymous ,2002). Tetradium gennus is economically important because of their alimentary, industrial and medicinal applications (Seidemann, 2005; Chase et al., 1999) Species of this genus are medicinal plants and have economic importance as sources of edible fruits, oils, wood, raw materials for industries, ornamentals, culinary applications, in previews studies isolated active chemicals compounds from Tetradium daniellii have biologic activities against some diseases (Yang, 2008; Da Silva et al. 2006; Adesina, 2005; Seidemann, 2005). in this study isolated active chemicals compounds from terpenoids compounds Terpenes are a wide-spread group of natural compounds with considerable practical significance which are produced by arrangement of squalene epoxide in a chair-chair-chair-boat arrangement followed by condensation. In our 


\section{University of Thi-Qar Joumal of Science (UTsci)}

Website: http://jsci.utq.edu.iq

Volume 6, Number 1, December 2016

everyday life we all encounter either directly or indirectly various terpenes, such as mono- and sesquiterpene components of essential oils, which contribute to the aroma of plants, triterpenes of different types included in all higher plants, ( Olukoga and Donaldson 2000 ; Szakiel et al. 1995).

\section{Material And Methods}

\subsection{Study plant}

Young buds and leaves of Tetradium daniellii were collected in 2014 from Guildford region near surrey university in united kingdom, The plant was classified in the Natural Products Research Group in chemistry department Faculty of Engineering \&Physical Sciences the University of Surrey

\subsection{Preparation of Crude Extract}

The leaves and buds of Tetradium daniellii were dried at $25^{\circ} \mathrm{C}$. The dried plant materials were ground to fine powder using grinding mills and extracted successively in a Soxhlet extractor using dichloromethane (DCM). The extracts were filtered and the solvent was evaporated, and collected the crude extract. (Mulholland et al.,2013).

\subsection{Isolation and purification of compound}

For the isolation process the following techniques of column chromatography and thin layer chromatography (TLC) were used. Different size columns were used for column chromatography, ranging from 2-6 $\mathrm{cm}$ diameter depending on the purification stage and the amount of the sample available. The separation of compounds was carried out using thin layer chromatographic analysis technique and size-exclusion column chromatography over Sephadex using $(\mathrm{CH} 2 \mathrm{Cl} 2$ : Hexane, 1:1) as the mobile phase. TLC analysis was carried out on $0.2 \mathrm{~mm}$ silica gel, aluminum-backed plates (Merck Art.5554) (Mulholland et al.,2013).

\subsection{Analysis spectral terpenoidcompound}

Various spectroscopic techniques including NMR, FTIR, TLC and MS analysis were used to identify the compound from Tetradium daniellii extract.

\subsubsection{Nuclear Magnetic Resonance Spectroscopy (NMR)}

Nuclear Magnetic Resonance spectroscopic experiments were performed on a $500 \mathrm{MHz}$ Bruker AVANCE NMR spectroscopy at University of Surrey in United kingdom. The spectra were recorded in either deuterated chloroform $(\mathrm{CDCl} 3)$ or deuterated methanol (CD3OD).

\subsubsection{Mass Spectrometry (MS)}

High resolution electron impact mass spectrum were acquired by using a Hewlett Packard G1800A GCD system at University of Surrey in United kingdom.

\subsubsection{Fourier Transform Infrared Spectroscopy (FTIR)}

Infrared spectra were recorded using a PerkinElmer (2000 FTIR) spectrometer. The samples were dissolved in chloroform and analyzed using $\mathrm{NaCl}$ plates

\subsection{Animals}

Rabbits weighting 1.5-2.0 Kg were procured from central animal house of Basra University, Basra, Iraq .Animals were kept in clean polypropylene cages and fed on standard antibiotic free diet. All animals were kept in fast for $24 \mathrm{hr}$. before staring the experiments (Manohar et al.,2012).

\subsubsection{Hyperglycemia Induction of Rabbits}

\subsection{Effect of Lup-20(29)-ene-3, 28-diol (Betulin) on glucose level in alloxan -induced diabetic rabbits}

Twelve fasted hyperglycemic rabbits were divided into two equal groups. The first was given $3 \mathrm{ml}$ of normal saline and considered as a control group while the second group was given $0.2 \mathrm{gm} / \mathrm{kg}$ body weight of (Lup-20(29)-ene-3, 28-diol (Betulin) dissolved in 3ml of normal saline which was considered as treatment group. Blood samples were collected at times (0 (as fasting), 2,4,6 and $24 \mathrm{hrs}$ ). The glucose concentrations were measured at each time point (Sultan and AbdulRahman ,.2009) . 


\section{University of Thi-Qar Joumal of Science (UTsci)}

Website: http://jsci.utq.edu.iq

Volume 6, Number 1, December 2016

\subsection{Statistical Analysis}

The statistical analysis was carried out for all experiments of hyperglycemic rabbits by one way method using ANOVA method of variance analysis using SPSS Version 14-2006 for testing presence of significant differences between control and treatment means.

\section{Results}

\subsection{Qualitative and quantitative analysis of triterpenes extracted from Tetradium daniellii}

\subsubsection{Triterpenes test}

$1 \mathrm{ml}$ of concentrated of sulphuric acid was added to $1 \mathrm{ml}$ of oils dissolved in $1 \mathrm{ml}$ of chloroform the purplered formed indicates the presence of triterpenes (Harborne , 1984).

\subsection{Preliminary chemical screening}

\subsubsection{Thin Layer Chromatography (TLC)}

TLC results of terpenoid extract using after hydrolysis showed the presence of one spot that indicate the present one terpenoid compound. Therefore it was separated by TLC, using ( 22\%DCM:78\% Ethyl acetate ) as eluent. The sample was lined across the TLC plate, $1 \mathrm{~cm}$ from the bottom of the plates. The plates were then placed in chromatography tanks and left to develop in the desired solvent system. This process was carried out four times. The compounds of interest successfully separated. These were detected and marked under UV light and anisaldehyde spray regent and heating

3.3. Structural elucidation of active chemical compound Lup-20(29)- ene-3, 28-diol (Betulin)

\subsubsection{GC-Mass Spectrum}

The Mass spectrum recorded of the terpenoid compound isolated from the leaves of Tetradium daniellii shown in Fig(1) it showed The abundance and $\mathrm{m} / \mathrm{z}$ Packets .

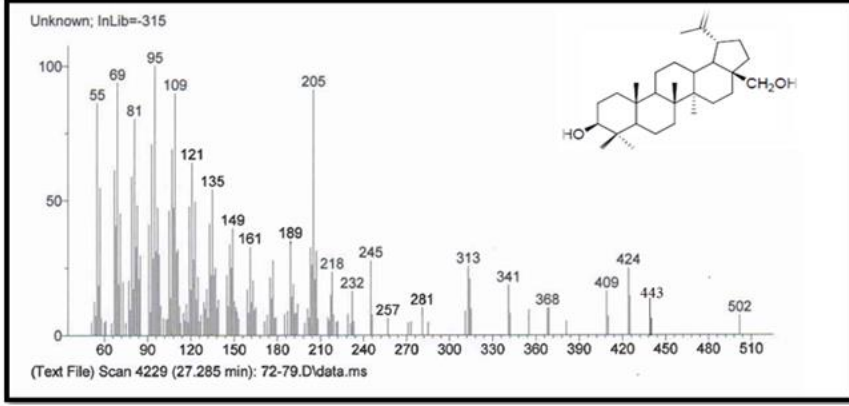

Fig (1) Mass Spectrum for Lup-20(29)-ene-3, 28-diol compound isolated from Tetradium daniellii

\subsubsection{F T-IR spectrum}

The infrared spectrum recorded of the compound isolated from the leaves of Tetradium daniellii is shown in fig(2) and table (2) showed The intensity of the absorption Packets and structure groups

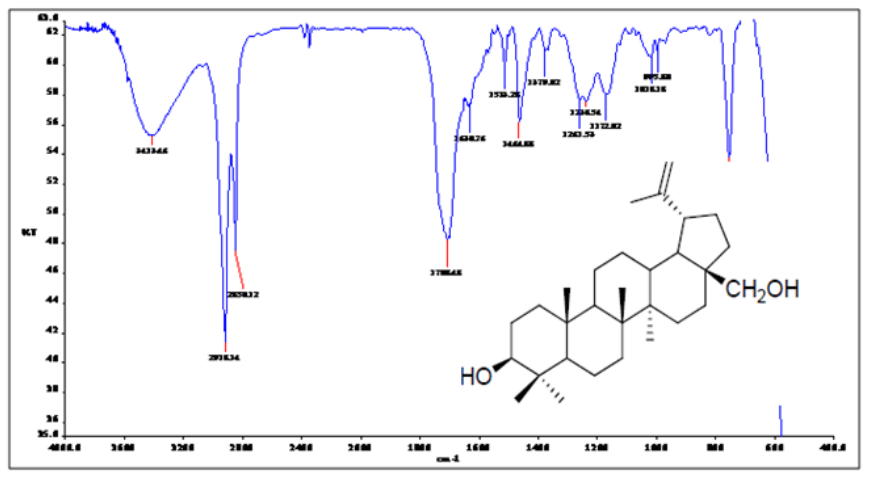

Fig (2) FT-IR Spectrum for Lup-20(29)-ene-3, 28-diol compound isolated from Tetradium daniellii

Table (2) The intensity of the absorption packets and wave number

\begin{tabular}{|c|c|c|c|}
\hline $\begin{array}{c}\text { Wave number } \\
\mathbf{c m}^{-1}\end{array}$ & Group & Vibration Type & Intensity \\
\hline $\mathbf{3 4 1 2 . 4 6}$ & OH & Stretching & Strong \\
\hline $\mathbf{2 9 1 8 . 1 4}$ & CH & Sym. Stretching & Strong \\
\hline $\mathbf{2 8 5 0 . 1 2}$ & CH & A sym. Stretching & Strong \\
\hline $\mathbf{1 6 2 0 . 7 6}$ & C=C & Bending & Strong \\
\hline $\mathbf{1 1 7 2 . 0 0}$ & C-O & Stretching & Strong \\
\hline
\end{tabular}

\subsubsection{Nuclear Magnetic Resonance Spectroscopy (NMR)}




\section{University of Thi-Qar Joumal Of Science (UTsci)}

Website: http://jsci.utq.edu.iq

\section{Volume 6, Number 1, December 2016}

Email: utjsci@utq.edu.iq

1H NMR, 13C NMR spectra of compound Lup20(29)-ene-3, 28-diol (Betulin) isolated from the leaves of Tetradium daniellii is shown in $\operatorname{Fig}(3)$,Fig(4) and Fig (5) which show chemicals shift for hydrogen groups and carbons atoms.

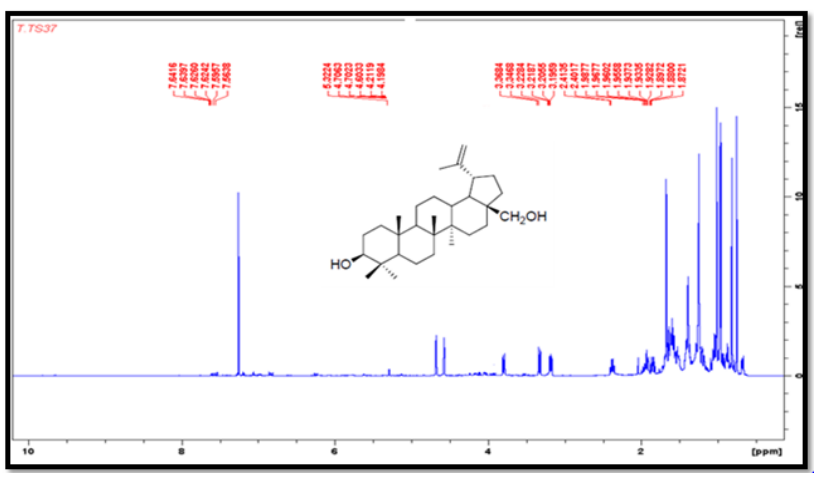

Fig. $3{ }^{1}$ H NMR spectrum for Lup-20(29)-ene-3, 28-diol compound isolated from Tetradium daniellii in $\mathrm{CDCl}_{3}$

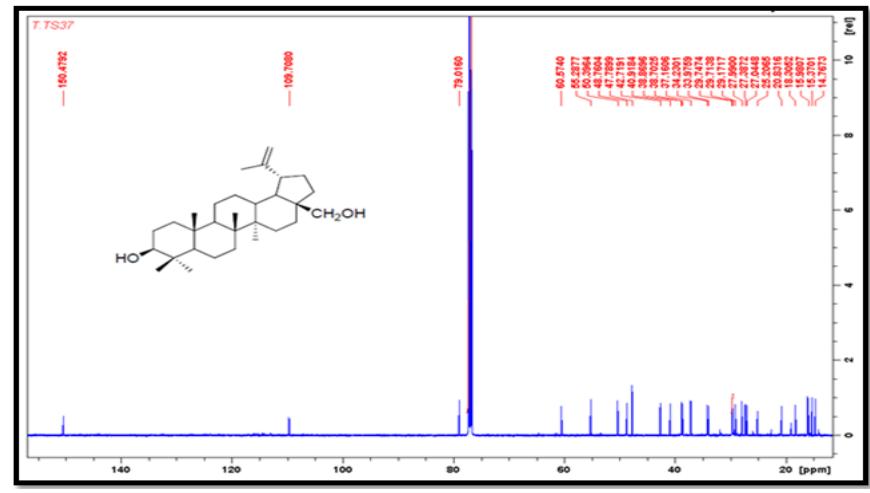

Fig.4 ${ }^{13} \mathrm{C}$ NMR spectrum for Lup-20(29)-ene-3, 28-diol compound isolated frozm Tetradium daniellii in $\mathrm{CDCl}_{3}$

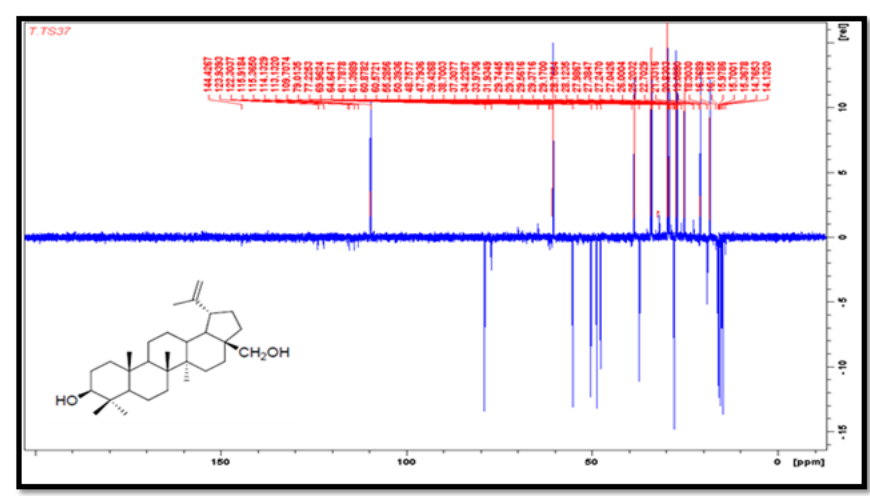

Fig.5 Dept spectrum for Lup-20(29)-ene-3, 28-diol compound isolated from Tetradium daniellii in $\mathrm{CDCl} 3$

\subsection{Hypoglycemic Action of Oral}

Administrationof Lup-20(29)-ene-3, 28-diol of

Tetradium daniellii leaves on Blood Glucose

\section{Conc. in Normalglycemic rabbits}

The oral administration of Lup-20(29)-ene-3, 28diol compound a significant result to decrease glucose conc. was found at times $6 \mathrm{hrs}(\mathrm{P}<0.05)$ and a significant decrease occurred at $24 \mathrm{hrs}(\mathrm{P}<0.05)$, when compared with control group as shown in table (3).

Table (3): Action of oral administration Lup-20(29)-ene3, 28-diol of Tetradium daniellii on blood glucose

\begin{tabular}{|c|c|c|c|c|c|c|}
\hline \multirow{2}{*}{$\begin{array}{c}\text { Extract and } \\
\text { Dose }(\mathrm{gm} / \mathrm{kg})\end{array}$} & \multirow[t]{2}{*}{$\mathrm{N}$} & \multicolumn{5}{|c|}{ Blood glucose conc. $(\mathrm{mg} / 100 \mathrm{ml})$} \\
\hline & & $0 \mathrm{hrs}$ & $2 \mathrm{hrs}$ & $4 \mathrm{hrs}$ & $6 \mathrm{hrs}$ & $24 \mathrm{hrs}$ \\
\hline Control 3m 1 & 6 & $123.89 \pm$ & $123.00 \pm$ & $121.02 \pm$ & $120.00 \pm$ & $117.5 \pm$ \\
\hline normal saline & & 3.46 & 2.68 & 3.21 & 3.23 & 1.34 \\
\hline $0.2 \mathrm{~g} \mathrm{~kg}$ (Betulin) & 6 & $127.12 \pm$ & $125.70 \pm$ & $123.10=$ & $96.02^{\circ} \pm$ & $102^{\circ} \pm$ \\
\hline & & 2.68 & 1.43 & 2,60 & 4.22 & 4.61 \\
\hline
\end{tabular}

\subsection{Effect of Oral Administration of Lup-20(29)- ene-3, 28-diol on blood glucose level in} hyperglycemic rabbits

The effect of Lup-20(29)-ene-3, 28-diol compound isolated from Tetradium daniellii on blood glucose level. In hyperglycemic rabbits at deferent times after oral administration, is indicated in table (4). It was found that extract decreases significantly glucose conc. at $4 \mathrm{hrs}(\mathrm{P}<0.05)$ and a significant decreasing occurred at $6 \mathrm{hrs}(\mathrm{p}<0.01)$. The greatest significant decreasing was recorded at $24 \mathrm{hrs}(\mathrm{P}<0.001)$.

Table (4): Action of oral administration of Lup-20(29)ene-3, 28-diol of Tetradium daniellii blood glucose conc. in hyperglycemic rabbits

\begin{tabular}{|c|c|c|c|c|c|c|}
\hline Extract and & $\mathrm{N}$ & \multicolumn{5}{|c|}{ Blood glucose conc. (mg/100 ml) } \\
\cline { 3 - 7 } Dose $(\mathrm{gm} / \mathrm{kg})$ & & $0 \mathrm{hrs}$ & $2 \mathrm{hrs}$ & $4 \mathrm{hrs}$ & $6 \mathrm{hrs}$ & $24 \mathrm{hrs}$ \\
\hline Control $3 \mathrm{~m} 1$ & 6 & $325.22 \pm$ & $321.52 \pm$ & $316.00 \pm$ & $308.92 \pm$ & $297.25 \pm$ \\
normal saline & & 3.26 & 3.45 & 2.33 & 6,00 & 3.42 \\
\hline $0.2 \mathrm{~g} \mathrm{~kg}$ (Betulin) & 6 & $334.50 \pm$ & $330.4 \pm$ & $259.91^{*} \pm$ & $218.18^{* *} \pm$ & $178.67^{* * *} \pm$ \\
& & 1.59 & 6.34 & 4.52 & 7.30 & 5.86 \\
\hline
\end{tabular}

$\mathrm{P}^{*}<0.05, \mathrm{P}^{* *}<0.01, \mathrm{P}^{* * *}<0.001, \mathrm{~N}=$ number of rabbits in each group. 


\section{University of Thi-Qar Joumal Of Science (UTsci)}

Website: http://jsci.utq.edu.iq

Volume 6, Number 1, December 2016

Email: utjsci@utq.edu.iq

Physical description: amorphous solid

Solubility: soluble in chloroform and ethylacetate

Melting Point: $249-253{ }^{\circ} \mathrm{C}$ (determined by open

Capillary method)

$\mathrm{R}_{\mathrm{f}}$ Value: 0.584 in $\mathbf{2 2} \% \mathrm{DCM}+\mathbf{7 8 \%}$ ethyl acetate

\section{Discussion}

\subsection{Structural elucidation of compound Lup- 20(29)-ene-3, 28-diol}

FT-IR spectrum of isolated compound gave characteristic peaks of groups present in the isolated compound like $\mathrm{C}-\mathrm{H}$ (alkane), $-\mathrm{CH} 3$ (bending), $\mathrm{C}=\mathrm{C}, \mathrm{C}-$ $\mathrm{O}$ and - $\mathrm{OH}$ group as show fig (1).

Mass spectroscopy of isolated compound was performed, by High resolution mass technique, showing a molecular ion peak at $M+1$. at 443 , while calculated molecular weight of betulin (molecular formula$\left.\mathrm{C}_{30} \mathrm{H}_{50} \mathrm{O}_{2}\right)$ is 442 as show fig( $(2)$.

$\mathbf{H}^{\mathbf{1}}$ - NMR spectroscopy was used for the confirmation of structure of isolated compound; in which various peaks in $\mathrm{CDCl}_{3}$ were found at $\delta$ value

1H-NMR, $4.70(\mathrm{~s}, 1 \mathrm{H}), 4.48(\mathrm{dd}, J=4.6,1 \mathrm{H}), 4.19(\mathrm{~d}$, $1 \mathrm{H}), 3.8(\mathrm{~d}, \mathrm{H}) \quad 3.38(\mathrm{H}), 3.2(\mathrm{q}, \mathrm{H}) \quad, 2.40-2.42(\mathrm{~m}, 1 \mathrm{H})$, $1.96-1.90(\mathrm{~m}, 5 \mathrm{H}), 1.80-1.9(\mathrm{~m}, 17 \mathrm{H}), 1.15-1.11(\mathrm{~s}$, $3 \mathrm{H}), 1.10-0.90(\mathrm{~m}, 1 \mathrm{H}), 1.05(\mathrm{~s}, 3 \mathrm{H}), 0.99(\mathrm{~s}, 3 \mathrm{H}), 0.95$ $(\mathrm{s}, 3 \mathrm{H}), 0.86(\mathrm{~s}, 3 \mathrm{H}, 0.82$ (s, 3H), as show Fig.(3) and it shows the presence of 50 hydrogen in the compound, and $\delta$ value of $13 \mathrm{C} \mathrm{NMR}\left(\mathrm{CDCl}_{3}, 400\right.$ $\mathrm{MHz})$ 13C NMR (CDCl3, $125 \mathrm{MHz}) \delta 150.4$ (C20),109.7 (C-29), 79.01 (C-3), 60.5 (C-28),55.4 (C-5), 50.3 (C-9), 48.7 (C-19), 47.7 (C-17), 42.7 (C-18), 40.9 (C-14), 38.8 (C-8), 38.9(C-1), 38.7 (C-4), 37.1 (C-10), 34.2 (C-13),33.9 (C-7), 29.74 (C-22), 29.71 (C-21), 29.1(C-16), 27.9 (C-23), 27.3 (C-2), 27.0 (C-15),25.2 (C-12), 20.8 (C-11), 18.3 (C-30), 15.9 (C-6), 15.3 (C25), 14.9 (C-26), 14.7 (C-24),14.1 (C-27) as show Fig.(4 )and Fig(5)

On the basis of characterization studies of isolated compound, it was concluded that the isolated compound betulin and its structure is determined as follows. it can be concluded that the isolated compound is similar to the molecular formula $\mathrm{C}_{30} \mathrm{H}_{50} \mathrm{O}_{2}$.

4.2. Physical Properties of Lup-20(29)-ene-3, 28-diol Colour: yellowish white

\subsection{Hypoglycemic effects of Active Chemical Compound (Lup-20(29)-ene-3, 28-diol) Isolated from Leaves of Tetradium daniellii in Normalglycemic and Hyperglycemic Rabbits}

It was observed from table (3) and table (4), that Tri terpenoid compound isolated from pods of plant decreased blood glucose conc. in hyperglycemic rabbits significantly because this compounds and most terpenoids active compounds have an antioxidant activity to capture free radicals, therefore these chemical compounds product the insulin hormone from free radicals and then decreasing oxidation of this hormone (Milner ,1994). Betulin and betulinic acid are naturally occurring pentacyclic triterpenes showing cytotoxicity towards a number of cancer cell lines (Drag et al.,2009).

Betulin also occurs as the palmitate in the glue firm bark of Trochodendron aralioides.The antiphlogistic activity of betulin was confirmed in various experimental modelsStudies on the activity of a methanolic extract from the rhizomes of $N$. nucifera, as well as betulin and betulinic acid revealed a marked inhibition of the carrageenin- and serotonin-induced rat paw edema, which was comparable to that of the standard anti-inflammatory agents phenylbutazone and dexamethazone. (steroid triterpenes), ( Recio et al. 1995);( Patočka,2003).By general Triterpenoids were among the bioactive constituents reported for antidiabetic activity of medicinal plants ; their mechanism of action has been attributed to inhibition of $\alpha$-amylase and $\alpha$-glucosidase (Nkobole et al .,2011) .Although the mechanism of action was not determined, sitosterol(one of tri trpenoids) has been shown as the active principle behind the hypoglycemic activity shown by extract of Ipomoea digitata tuber in streptozotocin-induced diabetic rats (Pandey et al.,2013). Sitosterol has also been shown to be the active principle in antihyperglycemic activity of Swietenia macrophylla seed extracts in normoglycemic rats undergoing glucose tolerance tests (Hashim et al.,2013). Also clinical studies (Gao et al.,2009) have shown that betulin (3ß-lup-20(29)-en-3,28-diol), was effective against a variety of tumors. Betulin causes 


\section{University of Thi-Qar Joumal Of Science (UTsci) \\ Website: http://jsci.utq.edu.iq}

Volume 6, Number 1, December 2016

some types of tumor cells to start a process of selfdestruction called apoptosis and can slow the growth of several types of tumor cells.Recent studies( Tilford ,1997) have proved that betulin, inhibited the maturation of Sterol regulatory element-binding protein (SREBPs). Inhibition of SREBP by betulin decreased the biosynthesis of Cholesterol and fatty acid. In vivo, betulin ameliorated diet-induced obesity, decreased the lipid contents in serum and tissues, and increased insulin sensitivity. Furthermore, betulin reduced the size and improved the stability of atherosclerotic plaques. (Alakurtti et al., 2006).

\section{$\underline{\text { References }}$}

Alakurtti, S; Makela, T; Koskimies, S; YliKauhaluoma, J (2006). harmacological properties of the ubiquitous natural product betulin . Eur. J. Pharm. Sci. 29 (1): 1-13.

American Diabetes Association (ADA) (2012).Diagnosis and Classification of Diabetes Mellitus (DIABETES CARE, VOLUME 35, SUPPLEMENT 1, )

Anand, K.K; Singh ,B; Chand ,D;Chandan, B.K and Gupta ,V(1989). Effect of Zizyphus sativa leaves on blood glucose levels in normal and alloxandiabetic rats. J Ethnopharmacol , 27:121-125.

Anonymous, (2002) . Evodia fruit (Fructus Evodiae). www.healthphone

com/consump_english/encyclopedia/

chinese_herbal_files/evodia fruit.htm (accessed 6 December 2002).

Andrade-Cetto, A and Heinrich,M .(2005). Mexican plants with hypoglycaemic effect used in the treatment of diabetes Journal of Ethnopharmacology 99 (2005) 325-348

Chauhan A, Sharma PK, Srivastava P, Kumar PN, Dudhe R. (2010) Plants Having Potential Antidiabetic Activity: A Review. Der Pharmacia Lettre 2: 369-387.

Da Silva, S. L., Figueredo, P. M. S; Yano, T. (2006). Antibacterial and Antifungal Activities of Volatile Oils from Zanthoxylum rhoifolium Lam. Leaves. Pharmaceutical Biology, 44,657-659. ISSN: 1744-5116.

Das Gupta,p. and De .A.(2012).Diabetes Mellitus and its Herbal Treatment. International Journal of
Research in Pharmaceutical and Biomedical Sciences. Vol. 3 (2) , pp.706-708.

Drag,M ; Surowiak ,P ; Drag-Zalesinska,M ; Dietel ,M Lage ,H and Oleksyszyn,J(2009). Comparision of the Cytotoxic Effects of Birch Bark Extract,Betulin and Betulinic Acid Towards Human Gastric Carcinoma and Pancreatic Carcinoma Drug-sensitive and Drug-Resistant Cell Lines. Molecules, 14, 1639-1651; doi: 10.3390/molecules 14041639

El-Houri, R.B ; Dorota ,K ; Louise C. B. Olsen, S. B.; Lars, P, C.; Grevsen,k; Oksbjerg,N; Færgeman,N; Kristiansen,K and Kathrine, B. C .(2014). Screening for Bioactive Metabolites in Plant Extracts Modulating Glucose Uptake and Fat Accumulation. Hindawi Publishing Corporation Evidence- Based Complementary and Alternative Medicine Volume 2014, Article ID 156398.

Gao, Y; Xu, H; Lu, Z; Xu, Z (2009). "Quantitative determination of steroids in the fruiting bodies and submerged-cultured mycelia of Inonotus obliquus". Se pu 27 (6): 745-9.

Hashim, M.A; Yam, M.F; Hor, S.Y; Lim ,C.P; Asmawi, M,Z and Sadikun, A.(2013). Antihyperglycaemic activity of Swietenia macrophylla King (Meliaceae) seed extracts in normoglycaemic rats undergoing glucose tolerance tests. Chin Med ; 8: 11. Doi:

$10.1186 / 1749-8546-8-11$

Harborne ,J.B. (1984) Phytochemical Methods. 2nd ed., Chmpman and Hall, London, UK.

Hartley, T. G. (1981). A revision of the genus Tetradium (Rutaceae). Gardens' Bulletin, Singapore 34:91-131.

Khan,N.A.(2013). Anti-hyperglycemic effects of three medicinal plants in diabetic pregnancy: modulation of $\mathrm{T}$ cell proliferation. BMC Complementary and Alternative Medicine 2013, 13:77

Manohar, V. S ; Jayasree, T. ; Kishore,k.k ;Rupa, L.M; Dixit,R and Chandrasekhar,N.(2012) . Evaluation of hypoglycemic and 


\section{University of Thi-Qar Joumal Of Science (UTsci) \\ Website: http://jsci.utq.edu.iq \\ Email: utjsci@utq.edu.iq}

Volume 6, Number 1, December 2016

antihyperglycemic effect of freshly prepared aqueous extract of Moringa oleifera leaves in normal and diabetic rabbits. Journal of Chemical and Pharmaceutical Research( $J$. Chem. Pharm. Res)., 4(1):249-253.

Moore, D.J; Gregory, J.M; Kumah-Crystal ,Y.A and Simmons, J.H.(2009) Mitigating micro- and macro-vascular complications of diabetes beginning in adolescence. Vasc Health Risk Manag. 5:1015-31

Mulholland ,D.A;Mwangi,E.M;Dlova,N.C;Plant,N; Crouch,N.R and Coombes,P,H.(2013).

Non-toxic melanin production inhibitors from Garcinia Livingstonei (Clusiaccae).Journal of Ethnopharmacolgy .Vol.149.pp.570-575.

Nkobole, N; Houghton, P.J ; Hussein ,A and Lall, N.(2011). Antidiabetic activity of Terminalia sericea constituents. Nat Prod Commun ; 6: $1585-1588$.

Oseni, O.A. and Idowu, A.S.K. ( 2014). Inhibitory Activity of Aqueous extracts of Horseradiash Moringa oleifera (Lam) and Nutmeg Myristica fragrans (Houtt) on Oxidative Stress in Alloxan Induced Diabetic Male Wistar Albino Rats. American Journal of Biochemistry and Molecular Biology, 4: 64-75.

Pandey ,A.K; Gupta ,P.P and Lal, V.K.(2013). Preclinical evaluation of hypoglycemic activity of Ipomoea digitata tuber in streptozotocin-induced diabetic rats. J Basic Clin Physiol Pharmacol ; 24: 35-39.

Patočka ,J.(2003) .Biologically active pentacyclic triterpenes and their current medicine signification. Journal of Applied Biomedicine 1: 7 - 12, 2003. ISSN 1214-0287

Pavia, D. L., Lampman, G. M., Kriz, G. S., Vyvyan, J. R.(2009). Introduction to Spectroscopy. BrookslCole, Cengage Learing, USA, p. 656.

Seidemann, J. (2005). World Spice Plants: Economic Usage, Botany, Taxonomy. Springer-Verlag,p. 399-402, ISBN: 3540222790, Berlin
Sultan ,K.H and Abdul-Rahman,S.Y.(2009). Effect of fenugreek seeds boiled extracts on some physiological and productive traits in rabbits Journal for Iraqi inventory Sciences. University of Mussel :23(1) pp73- 79.

Szakiel ,A; Wasiukiewicz,I and Janiszowska,W (1995). Metabolism of [3-3H]oleanolic acid in the isolated Calendula officinalis leaf cells and transport of the synthesized glycosides to the cell wall and the extracellular space. Acta Biochim Pol 42:25-29.

Tang, J . J . (2011). Inhibition of SREBP by a Small Molecule, Betulin, Improves Hyperlipidemia and Insulin Resistance and Reduces Atherosclerotic Plaques . j. cmet 13 (1): 44-56.

Tilford, G. L. (1997), Edible and Medicinal Plants of the West, Missoula, MO: Mountain Press, ISBN 0-87842-359-1

Vincent,M.A..(2004). Tetradium danillii (Korean evodla ; Rutaceae ) as anescapein north America . The Michigan BOTANIST Vol.3.pp21-22

Wasfi,I.A; Bashir,A.K; Amiri, M.H. and bdullah,A.A.(1994).The effect of Rhazya stricta on glucose homeostasis in normal and streptozotcion diabetic rats." Ethnopharmacology,43:141-147.

Yang, X. (2008). Aroma Constituents and Alkylamides of Red and Green Huajiao(Zanthoxylum bungeanum and Zanthoxylum schinifolium). Journal of Agricultural and Food Chemistry, 56, 1689-1696. ISSN: 0021-8561.

Yessoufou ,A; Gbenou ,J; Grissa , O ; Hichami ,A Simonin,A.M Tabka ,Z; Moudachirou ,M ; Moutairou,M and Olukoga A and Donaldson,D .(2000). Liquorice and its health implications. J R Soc Health 120:83-89. 